\title{
Retraction Note: Impact of the learning set's size
}

\author{
Adil Korchi ${ }^{1} \cdot$ Mohamed Dardor $^{2}$ - El Houssine Mabrouk ${ }^{3}$ \\ Published online: 5 January 2021 \\ (C) Springer Science+Business Media, LLC, part of Springer Nature 2020
}

\section{Retraction note to Education and Information Technologies (2020) 25:4637-4657 https://doi.org/10.1007/s10639-020-10165-9}

The Editor-in-Chief has retracted this article (Korchi et al. 2020) because it significantly overlaps with a previously published paper by Salperwyck \& Lemaire (Salperwyck et al. 2011).

Adil Korchi disagrees with the retraction but has not explicitly stated whether he agrees to this retraction notice. The other authors did not respond to correspondence regarding this retraction.

\section{References}

Korchi, A., Dardor, M., \& Mabrouk, E. H. (2020). Impact of the learning set's size. Education and Information Technologies, 25, 4637-4657. https://doi.org/10.1007/s10639-020-10165-9.

Salperwyck, C., Salperwyck, V.L.C., Lemaire, V. (2011). Impact de la taille de l'ensemble d'apprentissage: une étude empirique. Confrence Internationale Francophone sur l'Extraction et la Gestion de Connaissance.

Publisher's note Springer Nature remains neutral with regard to jurisdictional claims in published maps and institutional affiliations.

The online version of the original article can be found at https://doi.org/10.1007/s10639-020-10165-9

Adil Korchi

adil.korchi@gmail.com

Mohamed Dardor

mohamed.dardor@usmba.ac.ma

El Houssine Mabrouk abounadah@yahoo.fr

1 Faculty of Sciences and Technologies, University Sidi Mohamed Ben Abdellah, Fez, Morocco

2 Department of Informatics, Faculty of Sciences, Dhar El Mehrez, Fez, Morocco

3 Faculty of Sciences and Technics, Moulay Ismail University, Errachidia, Morocco 